\title{
Population structure and species dynamics of Spisula solida, Diogenes pugilator and Branchiostoma lanceolatum along a temporal-spatial gradient in the south coast of Portugal
}

\author{
M. Dolbeth*, I. Viegas, F. Martinho, J.C. Marques, M.A. Pardal \\ Institute of Marine Research (IMAR), clo Department of Zoology, University of Coimbra, 3004-517 Coimbra, Portugal
}

Received 8 March 2005; accepted 1 August 2005

Available online 29 September 2005

\begin{abstract}
The population structure, dynamics and distribution of Spisula solida, Diogenes pugilator and Branchiostoma lanceolatum, common species in the south coast of Portugal, were studied in a spatial-temporal manner in order to understand the influence of cross-shore sediment transport and anthropogenic activities. Spisula solida is harvested commercially, whereas D. pugilator and B. lanceolatum are non-target species, with little information available on the population dynamics of these species. The study was performed in 2001-2002, and along a gradient of 100-5000 m from the coastline, corresponding to a depth gradient of between 1 and $32 \mathrm{~m}$ deep. Spisula solida was distributed preferentially at 3-12 m deep, and its distribution appeared to be influenced seasonally by the cross-shore sediment dynamics. Results suggested benthic recruitment in June. Some recruitments had no expression (year 2001) since adults were not present, which seems to be a direct impact of clams' fisheries. Diogenes pugilator showed preferential distribution at shallow depths, from 1.3 to $8 \mathrm{~m}$. Results suggested recruitments every 4 months, in June, February and October. Branchiostoma lanceolatum showed the widest distribution, from 7 to $26 \mathrm{~m}$ deep. Recruitment seemed to start in June until October, when it attained an abundance peak of juveniles. For both non-target species no clear effects of the cross-shore dynamics or the clams' fisheries impact were visible.
\end{abstract}

(C) 2005 Elsevier Ltd. All rights reserved.

Keywords: Spisula solida; Diogenes pugilator; Branchiostoma lanceolatum; population dynamics; hydrodynamics; fisheries

\section{Introduction}

Information on species' spatial and temporal distribution is important for the understanding of organism's interactions with each other and the environment (Dauvin et al., 2004). In marine soft sediments, physical disturbance seems to be a key factor controlling the spatial and temporal compositions of the populations inhabiting those areas (Dernie et al., 2003). This disturbance may be naturally induced, such as waves and tide impacts (Snelgrove et al., 1998; Hewitt et al., 2003), but may also be due to anthropogenic perturbations, such as

\footnotetext{
* Corresponding author.

E-mail address: mdolbeth@ci.uc.pt (M. Dolbeth).
}

fishing (Chícharo et al., 2002a,b; Gaspar et al., 2002; Dernie et al., 2003) and dredging activities (Sardá et al., 2000). At a smaller scale, complex biological interactions, which in turn control sediment properties, also play an important role in regulating patterns of the biota (Snelgrove et al., 1998; Reise, 2002; Hewitt et al., 2003).

In the south coast of Portugal (Algarve), the mean wave energy in the Algarve is considered low to moderate (Sá-Pires et al., 2002). Seasonally this energy may increase, mainly due to stormy episodes in winter (Sá-Pires et al., 2002), which may induce cross-shore sediment transport, from which the offshore transport may result in beach erosion (Rey and Bernardes, 2002). In order to understand these hydrodynamic seasonal differences, their impacts on the sediment transport and on the benthic subtidal communities, a survey took place 
in 2001-2002 along a depth gradient in Ancão Peninsula, Algarve coast. Within the macrobenthic community sampled, Spisula solida, a commercial clam, Diogenes pugilator and Branchiostoma lanceolatum, both non-target species, were recognized as common species. Spisula solida is one of the most harvested species in Algarve coast, where an important clam dredge fishery takes place (Gaspar and Monteiro, 1999; Gaspar et al., 1999; Chícharo et al., 2002a,b; Palma et al., 2003). The dredges are designed to dig clams out of the sediment, disturbing the seabed both in terms of physical structure and biological communities (Gaspar et al., 2003). Besides the impact on the $S$. solida populations, these fisheries may also have impacts on other non-target species, such as the hermit crabs, which frequently constitute the by-catch of these fisheries (Gaspar et al., 2002, 2003; Palma et al., 2003). Hermit crabs do not seem to be strongly affected by injuries caused by the dredges (Gaspar et al., 2002). The by-catch discards of the bivalve dredge fishery may also constitute an important source of food for benthic scavengers, such as D. pugilator (Chícharo et al., 2002b; Palma et al., 2003), therefore influencing their population dynamics. The lack of literature regarding the non-target species emphasized the necessity to understand their distribution patterns, population structure and the factors that potentially affect them in a spatial-temporal manner.

The present work therefore had three main objectives: (1) to study and provide information on the dynamics and population structure of an important commercial species and on two other poorly-known non-target species; (2) to assess the impact of the cross-shore sediment transport, a resultant of hydrodynamics, on their distributions patterns and (3) to detect potential effects of anthropogenic activities such as the fishing activities.

\section{Material and methods}

\subsection{Study site and experimental design}

The study was conducted in the south coast of Portugal in vicinity of Ria Formosa (Faro), which is a barrier island system, composed of five islands and two peninsulas, separated by inlets. Sampling occurred along a depth gradient to the east of the Ancão Peninsula (Fig. 1) where the delta effect was not felt. In this area, 14 sampling stations were defined along a perpendicular transect, as distance to the coastline $100,200,300,400,500,600,800,1000,1400,1800,2400$, $3000,4000,5000 \mathrm{~m}$ (Fig. 1). Surveys were limited by the ocean's roughness, totalling 7 sampling dates at June 2001, September 2001, February 2002, May 2002, June 2002, July 2002 and October 2002. On both June 2001 and February 2002 sampling did not occur at the $5000 \mathrm{~m}$ sampling station.

At each station and sampling date, hydrographical data and the physical and chemical parameters of seawater were measured. Biological material was collected using a Ponar grab $\left(248 \pm 2.51 \mathrm{~cm}^{2}\right.$ sediment). About 4 grabs were collected for each sampling point, which totals 383 replicates during

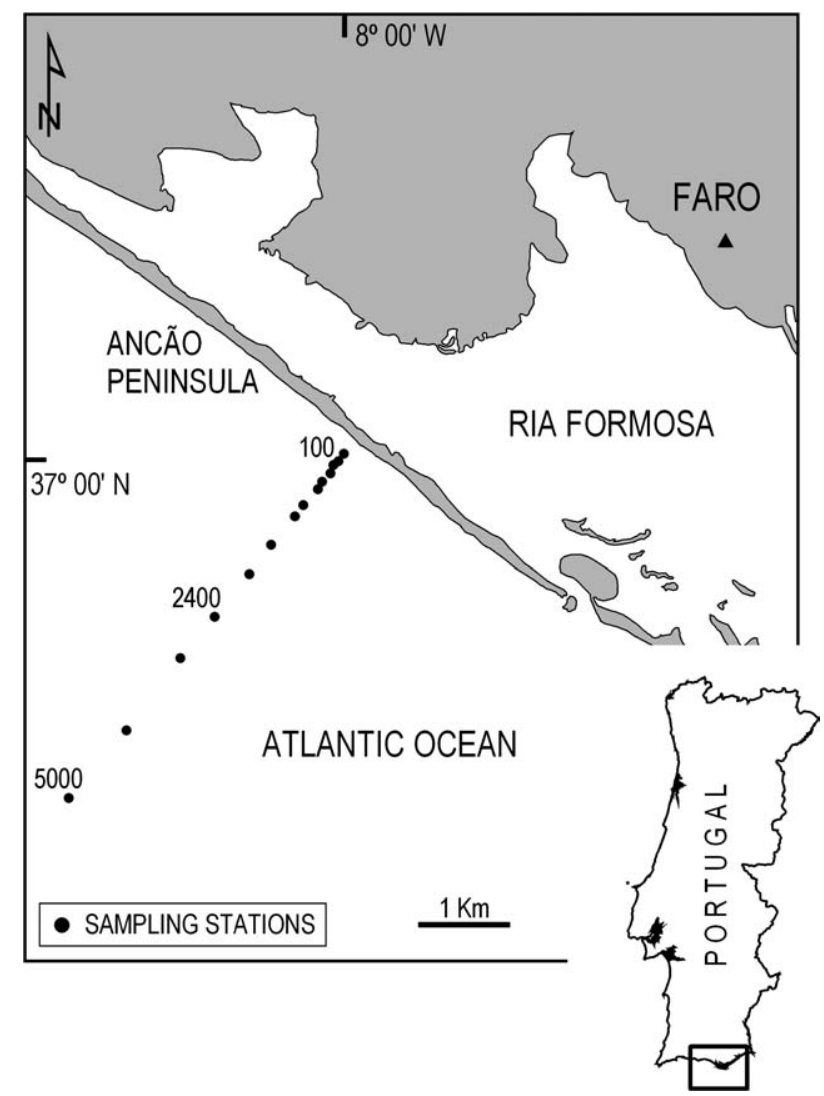

Fig. 1. Location of the sampling stations on the Ancão Peninsula, on the Ria Formosa barrier island system.

the sampling period. All samples were washed in a $500 \mu \mathrm{m}$ mesh bag. Additionally, 1 sample at each sampling point was colleted for sediment analysis in spring 2001, February 2002 and spring 2002.

In the laboratory, biological material was separated and preserved in a $4 \%$ buffered formalin solution. All individuals of Spisula solida, Diogenes pugilator and Branchiostoma lanceolatum were sorted, counted and measured. For S. solida, total body width (BW) was measured, for D. pugilator, cephalothoracic shield width (CSW) and length (CSL) and for B. lanceolatum, total body length (BL) was measured.

\subsection{Data analysis}

The species distribution along the transect was displayed using GIS. The depth lines were extrapolated using the depth obtained for each sampling point by the Kriging methodology, which is a method provided by ArcGIS to determine surfaces from predicted values.

The population structure of each species was defined by tracking recognisable cohorts from the successive sampling dates through size-frequency distribution analysis. These were performed with ANAMOD software, based on the probability paper method, which provides the mode, standard deviation and checks the reliability of the estimated parameters by application of $\chi^{2}$ and $G$ tests, $P=0.05$, following the procedure of Verdelhos et al. (2005). 


\section{Results}

\subsection{Environmental data}

The sampling stations comprised a depth gradient that varied from 1.3 to about $31.8 \mathrm{~m}$ deep (Fig. 2). In June 2001, the $5000 \mathrm{~m}$ sampling station was not sampled, so the maximum depth was only $27 \mathrm{~m}$ deep (Fig. 2A); in February 2002, due to ocean roughness, it was not possible to go to $5000 \mathrm{~m}$, but an intermediate station, at $4500 \mathrm{~m}$, was sampled with a maximum depth of $29 \mathrm{~m}$ (Fig. 2B). The seawater temperature showed an usual seasonal variation in temperate regions, with higher temperatures in spring and summer $\left(18.6 \pm 1.0{ }^{\circ} \mathrm{C}, \quad 19.6 \pm 0.3{ }^{\circ} \mathrm{C}\right)$ and lower in winter $\left(15.5 \pm 0.3{ }^{\circ} \mathrm{C}\right)$. Salinity $(35.5 \pm 0.9)$ and $\mathrm{pH}(8.2 \pm 0.2)$ showed no significant variations in space or time. Oxygen was the more variable parameter along the gradient, varying between 7.8 and $9.5 \mathrm{mg} \mathrm{l}^{-1}$.
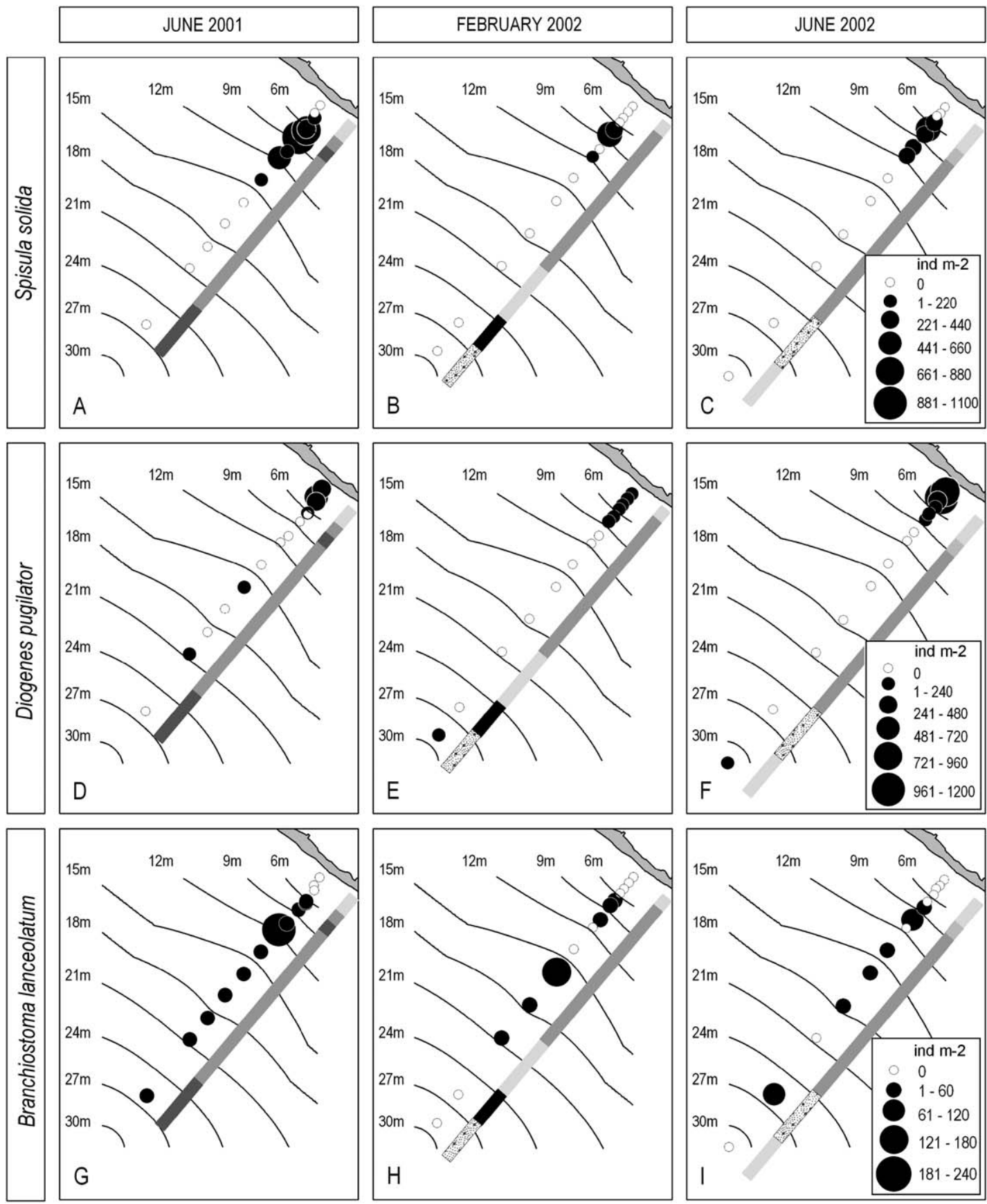

ine Sand $(0.125-0.25 \mathrm{~mm})$

Medium Sand $(0.25-0.5 \mathrm{~mm})$

Coarse Sand $(0.5-1 \mathrm{~mm})$

Very Coarse Sand $(1-2 \mathrm{~mm})$

Bare Rock

6:: Relict Deposit

Fig. 2. Spatial and temporal distribution patterns of the species along the depth gradient, with indication of sediment alterations for spring (June 2001, June 2002) and winter (February 2002) conditions. (A, B, C) Spisula solida; (D, E, F) Diogenes pugilator; (G, H, I) Branchiostoma lanceolatum. 
The sediment composition showed some variations along the depth gradient. In general, it was composed of fine sand at shallow depths and by coarser sands in deeper areas (Fig. 2). Along the temporal-spatial scales some important changes were observed. In spring 2001 (June 2001), the coarser sands started from about $7 \mathrm{~m}$ deep until $25.7 \mathrm{~m}$ deep, where very coarse sands appeared (Fig. 2A, D, G). In the winter (February 2002), coarser sands started from about $5 \mathrm{~m}$ deep until $20 \mathrm{~m}$, where fine sands appeared and afterwards a bare rock line was detected at $25.6 \mathrm{~m}$ depth; from this depth to $29 \mathrm{~m}$, very coarse sand and relict deposit occurred (Fig. 2B, E, H). Again in the spring, but 1 year later (June 2002), the fine sands extended until $8 \mathrm{~m}$ deep, followed by median and coarser sands until $23 \mathrm{~m}$, then the appearance of gravel and relict deposit from about $26 \mathrm{~m}$ deep followed by fine sands at $31 \mathrm{~m}$ deep (Fig. 2C, F, I).

\subsection{Spatial distribution}

Spisula solida was distributed preferentially between 3 and $12 \mathrm{~m}$ deep (Fig. 2A-C). In winter (February 2002), this species appeared further offshore (Fig. 2B), from $7 \mathrm{~m}$ deep. Abundance varied between 54 and 332 individuals (Fig. 3). The highest abundance was recorded in June 2001 and July 2002 and was mainly composed of small individuals (Fig. 3).

The population of Diogenes pugilator was found at shallow depths composed of fine sands, from 1.3 to $8 \mathrm{~m}$ deep (Fig. 2D-F). Occasionally, this species appeared, in small numbers, at 26-30 m deep, co-incidental with the appearance of relict deposits (Fig. 2E, F). No differences were found in the distribution patterns for spring and winter as the species occupied the same areas (Fig. 2D-F). Diogenes pugilator was mostly found in Hinia sp, Turritella sp and Bithium sp. shells and these were commonly associated with Hydractinia echinata. The highest abundance values were found in the spring months (e.g. June 2002, 230 ind.) and the lowest in the winter (e.g. February 2002, 33 ind.) (Fig. 3).

Branchiostoma lanceolatum showed the widest distribution, from depths of 7 to $26 \mathrm{~m}$, which corresponded mainly to coarse and very coarse sands (Fig. 2G-I). The few larger individuals found $(>30 \mathrm{~mm}$ ) were further offshore, from about $26 \mathrm{~m}$ deep. The highest abundance was found in October 2002 (440 ind.) and was mainly composed of young individuals (Fig. 3). The lowest abundance was attained in the spring months (18 and 24 ind., Fig. 3).

\subsection{Population structure, growth and life span}

Size-frequency polymodal distributions were analysed for the recognition of cohorts (Fig. 3). It was possible to discriminate 4 cohorts for Spisula solida, with cohort 1 (C1) constituted by only 1 adult individual. Recruits appeared once a year in June-July. From the recruits of June 2001 of cohort 3 (C3), almost no adults appeared in following months. The exception occurred in October 2002 with the appearance of two individuals with 13 and $15 \mathrm{~mm}$ wide, probably belonging to cohort 3 (16 months old). Again, the recruits of June 2002 from cohort
4 (C4) appeared in July 2002, but seemed to almost disappear in October 2002, as C4 almost did not exist in this last month (Fig. 3). The largest individual found was $30.5 \mathrm{~mm}$ wide (C1), likely corresponding to 30 months age. It was only possible to follow cohort 2 (C2), throughout, which within the sampled period, reached 28 months of age.

For Diogenes pugilator, 9 cohorts were recognized (Fig. 3). The results suggested recruitments in June, February and October, supported by the appearance of newly born cohorts (June, C5 and C8; February, C7; October, C6 and C9, Fig. 3). Larger individuals reached $8.6 \mathrm{~mm}$ in cephalothoracic shield length (CSL), with a life span of 21 months (October cohort, C3). The recruits of June 2001 (C5) reached 16 months, with a correspondent $5.9 \pm 0.25 \mathrm{~mm} \mathrm{CSL}$; and the recruits of February 2001 (C4) reached 20 months, 7.9 mm CSL.

With regard to Branchiostoma lanceolatum, 5 cohorts were identified, being the designated cohort 1 and cohort 2 (C1, C2) constituted each by only 1 ovigerous female. Recruitment seemed to start in June, with the prevalence of young individuals until October. It was only possible to follow cohort 3 throughout which within the sampled period, reached 28 months old, with individuals measuring $34.2 \mathrm{~mm}$ length. The largest individuals could attain $40.2 \mathrm{~mm}$ long, which corresponded to the ovigerous females $(\mathrm{C} 1$ and $\mathrm{C} 2)$. The population seemed to increase significantly in October 2002. C1 and C2 ovigerous females suggest that sexual maturity may be reached in the third year of life.

\section{Discussion}

The currents on the continental shelf of Portugal's south coast are generally weak (Chícharo et al., 2002b) and the mean wave energy is low to moderate (Sá-Pires et al., 2002). Yet, significant differences may occur seasonally, with higher hydrodynamics in the winter periods. Storm events are frequent in winter, induced by Atlantic swells, elevating the wave energy, with significant wave height higher than $3 \mathrm{~m}$ (Sá-Pires et al., 2002). Along with the mean wave height, the depth of closure can be representative of the cross-shore dynamics occurring in the system, as hydrodynamic changes are considered as the major acting forces. The depth of closure can be defined as a seaward limit, beyond which near-beach shore profiles show negligible vertical change, where limited net sediment transport is expected to occur seaward of this depth (Nicholls et al., 1998). In the present work, this depth was estimated to be about $3 \mathrm{~m}$ deep in spring and $10.4 \mathrm{~m}$ deep in winter (Ferreira, pers. comm.). Both measurements can be used to detect the impact of the cross-shore hydrodynamic impact on the species distribution, which is expected to be higher in the winter.

\subsection{Spisula solida}

Spisula solida was distributed preferentially at 3-12 m deep, which agrees with Gaspar et al. (1995, 1999) and 
Spisula solida
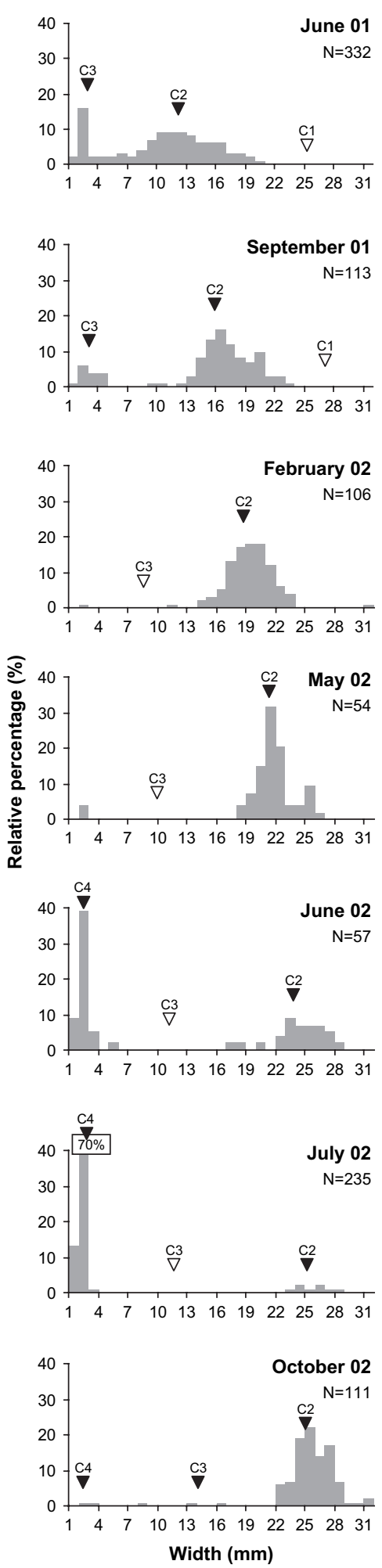

Diogenes pugilator
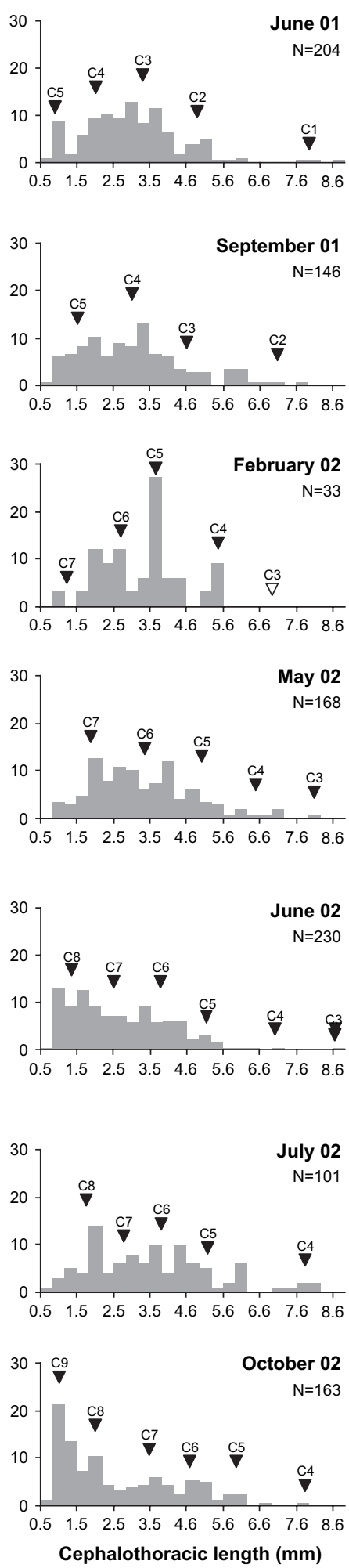

Branchiostoma lanceolatum
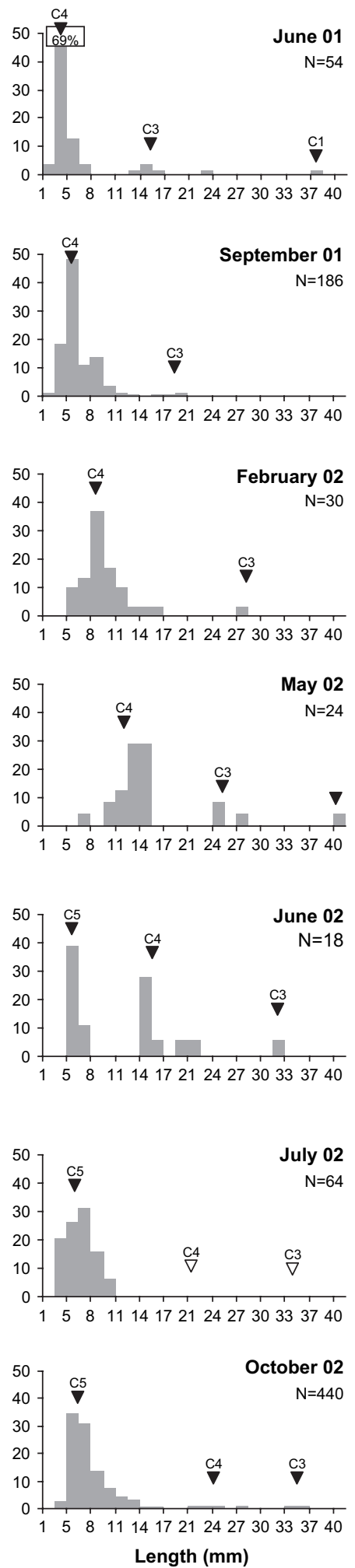

Fig. 3. Size-frequency distributions, with indication of the number of measured individuals $(N)$. Black arrowheads indicate identified cohorts $(C)$; blank arrowheads indicate the disappeared cohorts.

Fahy et al. (2003). The present study also suggested that $S$. solida may be seasonally influenced by the hydrodynamics, as in the winter, with a higher depth of closure, the clams seemed to distribute furthest from the coastline.
Abundance achieved its minimum and maximum values in the spring months, respectively, in early spring and late spring. The higher abundance is related with the recruitment patterns of the species, the lowest probably related with either previous 
Table 1

Data found on different populations of the species in study, and for other amphioxus species. BW, body width; CSL, cephalothoracic shield length; BL, body length

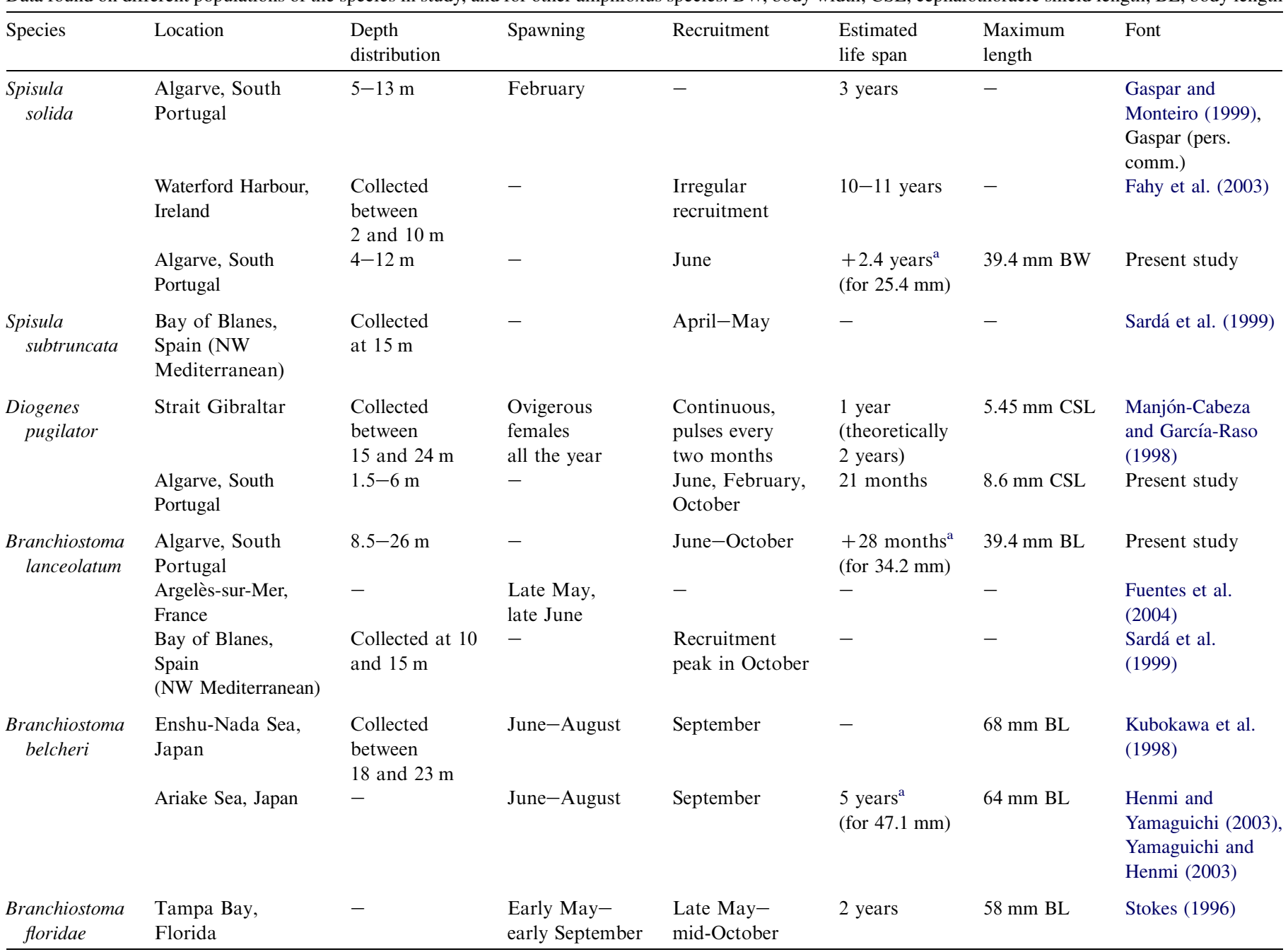

${ }^{\text {a }}$ Age of the living cohorts, not possible to determine life span.

fishing activities or natural causes. Results suggested that recruitment occurs once a year in late June-July. Nevertheless, the recruits of June 2001, from cohort 3 (C3), seemed not to appear in the following months, as no adults from that cohort appeared. The clams are sexually inactive from July to September, beginning gametogenesis in October and spawning in February (Gaspar and Monteiro, 1999), with the decrease in temperature. They reach sexual maturity in their first year of life, independently of size (Gaspar and Monteiro, 1999). This means, for the present results, that the adults responsible by gametogenesis of $\mathrm{C} 3$, in October 2000, would be the sexually mature adults from cohort $1(\mathrm{C} 1)$, which almost did not exist in June 2001. Consequently, the juvenile stock of June 2001 (C3) was relatively low and almost no adults appeared from those recruits. The juvenile stock of the next recruitment in June 2002, cohort 4 (C4), was much higher. Cohort 2 (C2) probably produced the new $\mathrm{C} 4$, as in October 2001, C2 was already sexually mature and there were sufficient adults to produce a reasonable stock. With a stock of juveniles in June and July 2002, the following C4 showed almost no individuals in October 2002.
Gaspar et al. (1995) determined the age and growth of Spisula solida, from a southern Portugal population from June 1992 to 1993, based on the internal bands of the shell (which provided the most accurate estimates). The samples of $S$. solida population were obtained through clam dredging which selectively catches adult individuals $(40 \mathrm{~mm}$ sieve bags). According to this study, clams with 19.7 and $28.6 \mathrm{~mm}$ were 1 and 2 year old, respectively. Similar results were also achieved when cohorts were determined, through size-frequency distribution analysis, similarly to the method applied in the present study, with $19.9 \pm 2.1$ and $29.1 \pm 1.8 \mathrm{~mm}$ for 1 and 2 year old, respectively (Gaspar, pers. comm.). These results differ from the present results, in which 1 and 2-year-old clams appeared to reach only $12.2 \pm 1.3$ and $23.5 \pm 1.6 \mathrm{~mm}$. These differences may be due to both environmental differences and anthropogenic disturbances. With regard to the environment, differences in food supply, which may be influenced by temperature and tidal currents, might have determined different clams' growth rates (Gaspar et al., 1995). With regard to anthropogenic disturbances, fishing activities might have reduced the stock of larger adults. Samples in 
the present study contained a smaller number of individuals and few $1+$ and $2+$ age adults and it seems reasonable to suggest that only the smaller individuals from each age were sampled, as the larger ones were probably caught, reducing each year class strength.

It was not possible to determine life span, but clams could reach 2.4 years at $25.4 \mathrm{~mm}$ (Table 1). Life span of this species has been stated before as 3 years for Algarve's south coast (Gaspar, pers. comm.) and as approximately 10 years for the Irish coast (Fahy et al., 2003).

Spisula solida is heavily fished in the south coast of Portugal (Gaspar and Monteiro, 1999; Gaspar et al., 1999; Gaspar et al., 2002; Chícharo et al., 2002a,b). The present study raises questions of proper fisheries management. Some years ago some management measures were applied, with the introduction of minimum legal landing length of $25 \mathrm{~mm}$ for S. solida, to allow spawning at least once (Gaspar et al., 1999, 2002). It seems reasonable to assume that the adults of $\mathrm{C} 1$, attaining about $25 \mathrm{~mm}$ in June 2001, were fished. If in the same period, or in the following winter, $\mathrm{C} 2$ individuals were also fished, the populations of $S$. solida would be seriously compromised. The same may have happened with $\mathrm{C} 4$, with its juveniles either being caught or predated, again compromising future recruitments. The low depth of closure (about $2.5 \mathrm{~m}$ deep), representative of the hydrodynamic force responsible for the dispersion of juveniles, and the existence of $25 \mathrm{~mm}$ adults in October 2002, the potentially fishing targets, make the hypotheses of predation or other natural causes of death of juveniles more likely. Predation on recently settled Spisula solidissima clams has also been suggested for punctual clams' disappearances in North American coast (Snelgrove et al., 1998; Weissberger and Grassle, 2003). It has also been reported that high mortality rates occur after recruitment periods for Spisula subtruncata in NW Mediterranean, in which the clams' population almost disappeared during autumn, followed by recruitment in April-May (Table 1) and high mortality in early summer (Sardá et al., 1999). Several works have focussed on the injuries inflicted by dredging fishing procedures on the macrobenthic species (Chícharo et al., 2002a,b; Gaspar et al., 2002). Although $S$. solida was considered not to be severely injured, as it is well protected by a thick shell, the predators' impact, attracted by disturbance of the fishing process itself, is expected to be high on the young bivalves, due to their small size and low thickness valves (Chícharo et al., 2002b). This would be also an important factor determining the year class strength (Chícharo et al., 2002b; Weissberger and Grassle, 2003) and consequent population development.

\subsection{Diogenes pugilator}

Hermit crabs, like Diogenes pugilator, are very specific to the food resources, gastropod shell availability and predators' presence (Tirelli et al., 2000; Barnes, 2003). The distribution of this species at lower depths is in accordance to the findings of Tirelli et al. (2000) and Manjón-Cabeza and García-Raso (1998). This pattern may be related to lower predators' pressure and preference for fine sands, despite the higher environmental stress. Environmental stress seems not to be a major problem, as in winter with higher hydrodynamics and consequent higher depth of closure, the distribution pattern of this species was unchanged. Other studies, in the Irish coasts, state that this species was often found buried beneath the beach surface. Its capability of burrowing rapidly into sand when disturbed (McGrath et al., 2000) seems to be an advantage to deal either with predation and physical stress. Occasionally some individuals were found at $26-30 \mathrm{~m}$ deep. The hermit crabs occupy empty gastropod shells, the utilization of which by this species is related to the local availability (Barnes, 2003) and competition (Tirelli et al., 2000; Pechenick et al., 2001). At 26-30 m deep, sediment was composed by relict deposit, which had a high portion of dead empty shells. Hermit crabs are more attracted to newly dead shells (Pechenick et al., 2001) but the local high availability of shells may have influenced the appearance of individuals at these depths.

Seasonal variations of abundance were found, with higher abundance in spring and lower in winter, which according to McGrath et al. (2000) are probably related with the lower water temperature. An opposite pattern was observed by ManjónCabeza and García-Raso (1998), where abundance increased in winter and decreased in spring, which may be related with migrations due to environmental factors.

Diogenes pugilator is a relatively fast-growing species. Manjón-Cabeza and García-Raso (1998) studied a population of D. pugilator from the Strait of Gibraltar (NE Atlantic) and found continuous recruitment, although with greater abundance of juveniles every two months (Table 1). The sampling periodicity of the present work was sparse in order to achieve conclusions on the reproduction pattern of such a fast-growing species. Nevertheless, contrarily to the findings of ManjónCabeza and García-Raso (1998), the recruitment seems to occur every 4 months, in June, February and October. Defined recruitment periods has also been proposed for other Atlantic populations, namely Roscoff, where recruitment appears to take place from May to September (Bourdon, 1965 in ManjónCabeza and García-Raso, 1998) and for the Irish coast, where ovigerous females were found from June to August (McGrath et al., 2000). February cohorts lasted for 21 months with $8.6 \mathrm{~mm}$ CSW, which are of wider length and life span than that mentioned by Manjón-Cabeza and García-Raso (1998) (Table 1). It was not possible to ascertain the life span of the June and October cohorts.

Fishing activities may not have a strong direct impact on Diogenes pugilator populations, because of its preferential distribution for lower depths and due to the protection of the shell they use as carapace. The individuals found were mainly in Hinia sp, Turritella and Gibulla sp shells, which in turn are highly resistant to the effects of entrapment in the net bags, providing an efficient protection against fishing operations (Gaspar et al., 2002). D. pugilator seems to benefit from the disturbance of the sea bottom caused by the fishing dredges, as it can access more feeding sources. This species has been described as scavenger and has been observed in the disturbed fishing areas shortly after the passage of the dredges (Chícharo et al., 2002b). 


\subsection{Branchiostoma lanceolatum}

Branchiostoma lanceolatum contrasts with the other species studied by its high mobility, which may also explain the wider range of distribution. Its distribution areas coincided with coarser and very coarser sands. The highest abundance of $B$. lanceolatum were achieved in September and October (186 and 440 individuals, respectively, composed mainly of young individuals), followed by a decrease in winter and achieving the lowest values in the spring months. The same pattern was also found in NW Mediterranean (Bay of Blane), where B. lanceolatum reached recruitment peak abundance in early autumn (October), followed by a steady decrease until winter and was almost absent during spring and summer (Sardá et al., 1999, 2000).

Recruitment seems to start in June. The predominance of young individuals in the sampled months July, September and October (with high abundances in the last two months) suggests the hypothesis of a recruitment period from June to October, achieving a recruitment peak in October, like observed in the Bay of Blane (Table 1; Sardá et al., 1999, 2000). Despite the scarcity of adults, the only identifiable ovigerous females were found in June and further offshore, which suggests that juveniles and adults may not share the same distribution areas. Water temperature seems to be an important factor controlling the breeding season of amphioxus (Fuentes et al., 2004). The spawning of cultured amphioxus has been induced by increasing the water temperature of the amphioxus' tanks (Fuentes et al., 2004). Spawning of the natural populations of Branchiostoma lanceolatum from Argelès-sur-Mer (France) seems to occur in late May and late June (Fuentes et al., 2004; Table 1), matching with the spring temperature increases. This reinforces the suggestion that spawning may have occurred in late May-June and that the recruitment period would follow through June-October, where it achieves maximum abundances. Similar behavior has been observed with the Florida amphioxus, Branchiostoma floridae, with a breeding season from early May to early September and new lancelet juveniles from late May through mid-October (Stokes, 1996; Table 1), and with the east-Asian amphioxus, Branchiostoma belcheri, which also showed a breeding season from June to August concentrating large number of juveniles in September (Kubokawa et al., 1998; Yamaguichi and Henmi, 2003; Table 1). It was not possible to determine the life span of B. lanceolatum. Estimations reach at least 2.4 years at $34.2 \mathrm{~mm}$ BL, which reveals a higher growth rate and life span than B. floridae (Table 1).

Regarding fishing activities, the mobility of this species is important. As small fishes are able to flow harmlessly out off the fishing gears (Palma et al., 2003), Branchiostoma lanceolatum is also potentially able to escape fishing dredges and nets. In fact, to our knowledge, there are no records of this species in the Portuguese clam dredge fishery catches (Gaspar et al., 2002).

\section{Conclusions}

This study has provided information on population dynamics about the three species. All species appear to occur spatially at distinct areas. Diogenes pugilator appeared in the surf zone, at finer sands. Spisula solida appeared between the surf and outer turbulent zone and its distribution was apparently influenced seasonally by the hydrodynamics. Branchiostoma lanceolatum showed the widest distribution within the outer turbulent zone, at coarser sands. Along the depth gradient studied, only two sexually mature amphioxus were found, suggesting that adults may occur deeper than $32 \mathrm{~m}$. Recruitments occur once a year in late spring for both $S$. solida and $B$. lanceolatum, while for $D$. pugilator three recruitments per year were identified, in late spring, winter and autumn. With regard to fishing activities, it was concluded that overfishing of $S$. solida in consecutive years can cause a drastic stock decrease. For the other species no harmful effects were observed. On the contrary, for $D$. pugilator the by-catch fauna of fisheries may be an important source of food input.

\section{Acknowledgements}

The authors are indebted to João Neto, Adriano Miguel and all colleagues that participated in field work, to João Pedro Cascalho for the determination of sediment grain size and to CICOMAR team for the hydrographical data. This work was supported by the CROP project (PDCTM/P/MAR/15265/ 1999).

\section{References}

Barnes, D.K.A., 2003. Local, regional and global patterns of resource use in ecology: hermit crabs and gastropods shells as an example. Marine Ecology Progress Series 246, 211-223.

Chícharo, L., Regala, J., Gaspar, M., Alves, F., Chícharo, M.A., 2002a. Macrofauna spatial differences within clam dredge-tracks and their implications for short-term fishing effects studies. Fisheries Research 54, 349-353.

Chícharo, L., Chícharo, M.A., Gaspar, M., Regala, J., Alves, F., 2002b. Reburial time and indirect mortality of Spisula solida clams caused by dredging. Fisheries Research 59, 247-257.

Dauvin, J.C., Thiébaut, E., Gesteira, J.L.G., Ghertsos, K., Gentil, F., Roper, M., Sylvand, B., 2004. Spatial structure of a subtidal macrobenthic community in the Bay of Veys (western Bay of Seine, English Channel). Journal of Experimental Marine Biology and Ecology 307, 217-235.

Dernie, K.M., Kaiser, M.J., Richardson, E.A., Warwick, R.M., 2003. Recovery of soft sediment communities and habitats following physical disturbance. Journal of Experimental Marine Biology and Ecology 285-286, 415-434.

Fahy, E., Carroll, J., O’Toole, M., 2003. A preliminary account of fisheries for the surf clam Spisula solida (L) (Mactracea) in Ireland. The Marine Institute, Marine Fisheries Services Division, Abbotstown Dublin 15. Fisheries Bulletin 21. Available from: http://www.marine.ie.

Fuentes, M., Schubert, M., Dalfo, D., Candiani, S., Benito, E., Gardenyes, J., Godoy, L., Moret, F., Illas, M., Patten, I., Pestarino, M., Fernadez, J.G., Albalat, R., Laudet, V., Vernier, P., Escriva, H., 2004. Preliminary observations on the spawning conditions of the European amphioxus (Branchiostoma lanceolatum) in captivity. Journal Experimental Zoology (Molecular and Developmental Evolution) 302B, 384-391.

Gaspar, M.B., Castro, M., Monteiro, C.C., 1995. Age and growth rate of the clam Spisula solida L., from a site off Vilamoura, south Portugal, determined from acetate replicas of shell sections. Scientia Marina 59, 87-93.

Gaspar, M.B., Monteiro, C.C., 1999. Gametogenesis and spawning in the subtidal white clam Spisula solida, in relation with temperature. 
Journal of the Marine Biological Association of the United Kingdom 79, 753-755.

Gaspar, M.B., Castro, M., Monteiro, C.C., 1999. Effect of tooth spacing and mesh size on the catch of the Portuguese clam and razor clam dredge. ICES Journal of Marine Science 56, 103-110.

Gaspar, M.B., Leitão, L., Santos, M.N., Sobral, M., Chícharo, L., Chícharo, A., Monteiro, C.C., 2002. Influence of mesh size and tooth spacing on the proportion of damaged organisms in the catches of the Portuguese clam dredge fishery. ICES Journal of Marine Science 59, 1228-1236.

Gaspar, M.B., Leitão, L., Santos, M.N., Chícharo, L., Dias, M.D., Chícharo, A., Monteiro, C.C., 2003. A comparison of direct of macrofaunal mortality using three types of clam dredges. ICES Journal of Marine Science 60, 733-742.

Henmi, Y., Yamaguichi, T., 2003. Biology of the amphioxus, Branchiostoma belcheri in the Ariake Sea, Japan I. Population structure. Zoological Science 20, 897-906.

Hewitt, J.E., Cummings, V.J., Ellisa, J.I., Funnella, G., Norkko, A., Talley, T.S., Thrush, S.F., 2003. The role of waves in the colonisation of terrestrial sediments deposited in the marine environment. Journal of Experimental Marine Biology and Ecology 290, 19-47.

Kubokawa, K., Azuma, N., Tomiyama, M., 1998. A new population of the amphioxus (Branchiostoma belcheri) in the Enshu-Nada Sea in Japan. Zoological Science 15, 799-803.

Manjón-Cabeza, M.E., García-Raso, J.E., 1998. Population structure and growth of the hermit crab Diogenes pugilator (Decapoda:Anomura:Diogenidae) from the northeastern Atlantic. Journal of Crustacean Biology 18, 753-762.

McGrath, D., Costello, M.J., Emblow, C., 2000. The hermit crab Diogenes pugilator (Roux, 1829) in Irish waters. Biology and Environment. Proceedings of the Royal Irish Academy 100B, 115-118.

Nicholls, R.J., Birkemeier, W.A., Lee, G., 1998. Evaluation of depth of closure using data from Duck, NC, USA. Marine Geology 148, 179-201.

Palma, J., Reis, C., Andrade, J.P., 2003. Flatfish discarding practices in bivalve dredge fishing off the south coast of Portugal (Algarve). Journal of Sea Research 50, 129-137.

Pechenick, J.A., Hsieh, J., Owara, S., Wong, P., Marshall, D., Untersee, S., Li, W., 2001. Factors selecting for avoidance of drilled shells by the hermit crab Pagurus longicarpus. Journal of Experimental Marine Biology and Ecology 262, 75-89.

Reise, K., 2002. Sediment mediated species interactions in coastal waters. Journal of Sea Research 48, 127-141.

Rey, S., Bernardes, C., 2002. Seasonal changes in a beach system of a high energy coast: an example from Areão beach (Aveiro, Portugal). Littoral 2002, The Changing Coast. EUROCOAST/EUCC, Porto, Portugal, pp. 353-354.

Sá-Pires, C., Ferreira, O., Matias, A., Dias, J.A., 2002. Preliminary evaluation of the morphological evolution of contrasting beaches of the Ria Formosa with relation to differences in refracted wave height. Littoral 2002, The Changing Coast. EUROCOAST/EUCC, Porto, Portugal, pp. 423-429.

Sardá, R., Pinedo, S., Martin, D., 1999. Seasonal dynamics of macroinfaunal key species inhabiting shallow soft-bottoms in the Bay of Blanes (NW Mediterranean). Acta Oecologica 20, 315-326.

Sardá, R., Pinedo, S., Grémare, A., Taboada, S., 2000. Changes in the dynamics of shallow sandy-bottom assemblages due to sand extraction in the Catalan Western Mediterranean Sea. ICES Journal of Marine Science 57, 1446-1453.

Snelgrove, P.V.R., Grassle, J.P., Butman, C.A., 1998. Sediment choice by settling larvae of the bivalve, Spisula solidissima (Dillwyn), in flow and still water. Journal of Experimental Marine Biology and Ecology 231, 171-190.

Stokes, M.D., 1996. Larval settlement, post-settlement growth and secondary production of the Florida lancelet (=amphioxus) Branchiostoma floridae. Marine Ecology Progress Series 130, 71-84.

Tirelli, T., Dappiano, M., Maiorana, G., Pessani, P., 2000. Intraspecific relationship of the hermit crab Diogenes pugilator: predation and competition. Hydrobiologia 439, 43-48.

Verdelhos, T., Neto, J.M., Marques, J.C., Pardal, M.A., 2005. The effect of eutrophication and coastal management on the bivalve Scrobicularia plana. Estuarine, Coastal and Shelf Science 63, 261-268.

Weissberger, E.J., Grassle, J.P., 2003. Settlement, first-year growth, and mortality of surfclams, Spisula solidissima. Estuarine, Coastal and Shelf Science 56, 669-684.

Yamaguichi, T., Henmi, Y., 2003. Biology of the amphioxus, Branchiostoma belcheri in the Ariake Sea, Japan II. Reproduction. Zoological Society of Japan 20, 907-918. 